The Journal of Animal \& Plant Sciences, 31(3): 2021, Page: 782-790

ISSN (print): 1018-7081; ISSN (online): 2309-8694

\title{
DUAL OPTIMIZATION OF MEDIUM COMPONENTS USING WEIGHTED STANDARDIZATION FOR ANTIBACTERIAL SPECTRUM AND CELL YIELD OF LACTOBACILLUS PLANTARUM SK1305 ISOLATED FROM PICKLED PEPPER
}

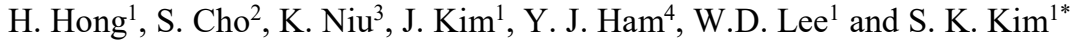 \\ ${ }^{1}$ Department of Animal Science and Technology, Konkuk University, Seoul, 05029, Korea \\ ${ }^{2}$ Animal Resources Research Center, Konkuk University, Seoul, 05029, Korea \\ ${ }^{3}$ Institute of Biological Resource, Jiangxi Academy of Sciences, Nanchang, 330029, China \\ ${ }^{4}$ Department of Beauty Stylist, Yeonsung University, Gyeonggi-do, 14011, Korea \\ *Corresponding author's E-mail:sookikim@konkuk.ac.kr
}

\begin{abstract}
The present study aimed to optimize medium component which maximize antibacterial spectrum and cell yield of Lactobacillus plantarum SK1305 at the same time. L. plantarum isolated from Korean traditional pickled pepper was used and its antibacterial activity against Salmonella typhimurium, Listeria monocytogenes, Burkholderia sp., Enterococcus faecalis, Salmonella gallinarum, and Staphylococcus aureus were investigated. Alteration of medium components was performed using a fractional factorial design and weighted standardization method was applied in optimization of medium components. Inversed probability of medium component effect was employed in weighting. Total of 15 medium ingredients: sucrose, maltose, molasses, yeast extract, corn steep liquor, whey, $\mathrm{K}_{2} \mathrm{HPO}_{4}, \mathrm{MnSO}_{4}$, $\mathrm{MgSO}_{4}$, tween 80, NaCl, $\mathrm{CH}_{3} \mathrm{COONa}, \mathrm{C}_{6} \mathrm{H}_{11} \mathrm{NO}_{7}, \mathrm{Na}_{2} \mathrm{SO}_{4}$, and $\mathrm{FeSO}$, were used as variables. The significant positive effects on cell yield were found for maltose and $\mathrm{FeSO}_{4}$. The effects of ingredients on the antibacterial spectrum were summarized using weighted standardization, and sucrose and $\mathrm{CH}_{3} \mathrm{COONa}$ were determined as the most important ingredients. These results provide useful information about medium ingredients for the improvement of the antibacterial spectrum of L. plantarum SK1305.
\end{abstract}

Key words: Lactobacillus plantarum; medium ingredients; antibacterial activity; cell yield; fractional factorial design.

https://doi.org/10.36899/JAPS.2021.3.0290

Published online December 07, 2020

\section{INTRODUCTION}

Lactic acid bacteria (LAB) have been widely used in various industrial fields such as fermented dairy food, direct fed microorganism for livestock and food preservatives. These broad applications are possible since $\mathrm{LAB}$ are regarded as an organism involved in Generally Regarded As Safe (GRAS), which can suppress the growth of pathogenic bacteria (Castellano et al., 2017). Antibiotics have been used to control pathogenic infection and to improve animal performance (Forte et al., 2016). However, many concerns induced by its abuse such as cross-resistance of antibiotics and occurrence of multidrug resistant pathogenic bacteria have been reported. And the use of antibiotics in animal husbandry is now strictly controlled in many countries. Probiotics have been developed to alternate the use of antibiotics as growth promoters, and $\mathrm{LAB}$ is the most-well known microorganism for probiotics. The beneficial roles of $\mathrm{LAB}$ are immune enhancement, competitive exclusion, production of organic acids and direct antibacterial activities (Castellano et al., 2017; Vieco-Saiz et al., 2019; Wang et al., 2015). The antibacterial activity or those spectrums against various pathogenic bacteria are reported to be varied depending on the genus and/or species of LAB (Ren et al., 2018). Other factors that can influence the antibacterial activity have been known as culture conditions consisting of temperature, $\mathrm{pH}$, growth stage and medium compositions (Yang et al., 2018). Therefore, selection of LAB (Castellano et al., 2017) and optimizing culture condition are crucial for getting an effective antibacterial activity from culture. Investigation of the optimum medium, which is specialized to a certain $\mathrm{LAB}$ is a primary step in development of fermentation process (Srivastava et al., 2015; Yoo et al., 2018). An one factor at a time (OFAT) method considering the effect of one factor while the others are kept at a fixed point has been traditionally applied because it did not require any complicated statistical experimental design. It is obviously an excellent procedure unless there are many factors that should be considered at the same time (Coman and Bahrim, 2011; Zhang et al., 2012). Fractional factorial design (FFD) is a statistical tool applicable to experimental design and analysis of system's responses with only few trials compared to OFAT (Cho et al., 2010; Soni et al., 2007). PlackettBurman design (PBD) is a frequently used FFD when only the main effects of variables are matter of interest (Cho et al., 2010).

In the present study, LAB showing antibacterial 
activity isolated from Korean traditional pickled pepper and investigated the effect of various medium ingredients on the antibacterial activity for animal pathogens using statistical methods.

\section{MATERIALS AND METHODS}

Chemical and media: The chemical and medium ingredients were purchased from Sigma Chemical Co. (St. Louis, Mo, USA) and Becton, Dickinson and Company (BD, Le Pont-de-Claix, France), respectively unless otherwise stated.

Isolation of LAB: Korean traditional pickled pepper was used as a source for bacterial isolation. It was serially diluted with sterilized $0.8 \% \mathrm{NaCl}$ solution and spread on MRS agar plates. The medium was incubated at $30{ }^{\circ} \mathrm{C}$ until a colony was detected, and the colony was transferred into MRS broth and then incubated for overnight $\left(30{ }^{\circ} \mathrm{C}, 150 \mathrm{rpm}\right)$. Culture supernatant was prepared after incubation by centrifugation $\left(4{ }^{\circ} \mathrm{C}\right.$, $1,028 \times 10 \mathrm{~g}$ for $10 \mathrm{~min}$ ) and then used for antibacterial activity assay. Finally, the strain showing antibacterial activity was selected.

Determination of antibacterial activity: Antibacterial activity was estimated using agar well diffusion assay according to Basualdo et al. (2007). Briefly, $100 \mu \mathrm{L}$ of pathogenic bacterial culture (optical density was about 1.0 at $600 \mathrm{~nm}$ ) was added to $10 \mathrm{~mL}$ of $0.8 \%$ water agar solution, which was kept at $60{ }^{\circ} \mathrm{C}$ to avoid solidification. And then the mixture was immediately poured on LB plate medium and let it be solidified at room temperature. A $6 \mathrm{~mm}$ hole in diameter was drilled and $100 \mu \mathrm{L}$ of culture supernatant was infused into the hole. The assay plates were then incubated at $37{ }^{\circ} \mathrm{C}$ for $24 \mathrm{~h}$ and the diameter of the clear zone was measured. For pathogenic bacteria in assay, Salmonella typhimurium KCTC 2514 (KCTC: Korean Collection for Type Cultures), Listeria monocytogenes KACC10550 (KACC: Korean Agricultural Culture Collection), Enterococcus faecalis KCTC 2011, Sal. gallinarum ATCC 9184, Staphylococcus aureus SK1213 (wild type) and Burkholderia sp. SK875 (wild type) were used. All strains were maintained using LB medium at $37^{\circ} \mathrm{C}$

Taxonomical identification: Identification of the isolated strain was performed based on $16 \mathrm{~S}$ ribosomal RNA gene sequence. The sequence was analyzed by polymerase chain reaction (PCR) with two universal primers: 27F (5'-AGA GTT TGA TCC TGG CTC AG3') and 1492R (5'-GGT TAC CTT GTT ACG ACT T- 3') (Weisburg et al., 1991). The PCR products were sequenced using ABI PRISM 3730XL DNA analyzer (Applied Biosystem, Franklin Lakes, NJ, USA). The identity of an isolated sequence was searched in GenBank.
A multiple alignment was performed using CLUSTRAL_W program (Thompson et al., 1994) with $16 \mathrm{~S}$ rRNA gene sequences of type strains involved in same genus with the bacteria. Phylogenetic tree of isolated strain was built based on the evolutional distance analysis using Maximum Composite Likelihood method (Lindsay, 1988). All identification procedures were performed using MEGA (Molecular Evolutionary Genetics Analysis) 4 program (Tamura et al., 2004; Tamura et al., 2007). Biochemical test was carried out using API 50 CHL kit (bioMérieux, Inc, NC, France), and the analysis was followed manufacturer's guide (Baradaran et al., 2012).

Cell yield: Cell yield was determined via viable cell counts on MRS agar plates. The number of colonies was enumerated and cell yield was expressed after logarithmic transformation of CFU (colony forming unit) based on 10 .

Screening of media ingredients for antibacterial spectrum: The effects of medium ingredients on the antibacterial activity of the isolated strain were screened using PBD. For variables, sucrose, maltose, molasses yeast extract, corn steep liquor, whey, $\mathrm{K}_{2} \mathrm{HPO}_{4}, \mathrm{MnSO}_{4}$, $\mathrm{MgSO}_{4}, \mathrm{NaCl}, \mathrm{FeSO}_{4}, \mathrm{CH}_{3} \mathrm{COONa}, \mathrm{C}_{6} \mathrm{H}_{11} \mathrm{NO}_{7}, \mathrm{Na}_{2} \mathrm{SO}_{4}$ and tween 80 were applied. All variables were assigned to two concentration levels (high and low) as summarized in Table 1. Total of 20 experimental run were constructed based on PBD (for X1, +, -, +, +, -, -, -, -, +, -, +, -, +, +, $+,+,-,-,+,-)$. Four dummy variables were set after 15 variables for the calculation of standard error. High and low levels for variables were denoted as +1 and -1 , respectively.

The effects of variables and their significance were calculated according to Chauhan et al. (2007). The main effect of variables were calculated by the difference between the sum of responses assigned to high levels of variables and the sum of responses from low levels of variables.

$$
E\left(X_{i}\right)=\frac{2\left(\sum A_{i}^{+}-\sum A_{i}^{-}\right)}{N}
$$

where, $E\left(X_{i}\right)$ is main effect of variable $X_{i} . A_{i}^{+}$ and $A_{i}{ }^{-}$are the responses from the trial where high and low levels of $X_{i}$ variable, respectively. The responses are antibacterial activities against various pathogenic bacteria. $N$ is the total number of trials. Experimental error was estimated by the variance that was calculated from dummy variables.

$$
V \quad=\sum\left(E_{a}\right)^{2} / n
$$

where, $E_{d}$ is main effect from dummy variable, and $n$ are number of dummy variables. The standard error of concentration effects is the square root of variance. The significance of each concentration effects of variables is calculated using student's $t$-test. 
Standardized effect on various pathogenic bacteria: To summarize the effects of variables on antibacterial activity against various pathogenic bacteria simultaneously, standardized effects were calculated by transformation of effects using standard normal distribution and inversed probability.

$$
Z_{i}^{n}=\frac{\left(E_{i}^{n}-\mu_{i}\right)}{\sigma_{i}} \times \frac{1}{p_{i}^{n}}
$$

where, $Z_{i}^{n}$ and $E_{i}^{n}$ is the standardized effect and the effect of $n^{\text {th }}$ variable against $i^{\text {th }}$ pathogenic bacteria. The $\mu_{i}$ and $\sigma_{i}$ are mean and standard deviation from all effects of variables against $i^{\text {th }}$ pathogenic bacteria. The $p_{i}^{n}$ is the probability of the effect of $\mathrm{n}^{\text {th }}$ variables against $i^{\text {th }}$ pathogenic bacteria. Finally, overall effects of variables were calculated by summing all standardized effects.

\section{RESULTS AND DISCUSSION}

Isolation and identification: In this study, SK1305 strain showing antibacterial activity was isolated and it was determined to be closely related to Lactobacillus plantarum ATCC14431 ${ }^{\mathrm{T}}$ (AF429479) with 99\% identity based on 16S rRNA gene sequence analysis (Fig. 1). The isolated strain was then designated as L. plantarum SK1305 (GenBank accession number: JX501236). Carbohydrate utilization patterns of $L$. plantarum SK1305 are summarized in Table 2. L. plantarum SK1305 is known to not be able to utilize glycerol, and the utilization of glycerol can be used for the distinguishable feature for $L$. plantarum from its intraspecies, L. pentosus that can utilize glycerol (Tajabadi et al., 2013).

Effects of medium ingredients on cell yield of $\boldsymbol{L}$. plantarum SK1305: In the cell yield, positive effects were found at sucrose, maltose, molasses, whey, $\mathrm{MnSO}_{4}$, tween 80, sodium sulfate and $\mathrm{FeSO}_{4}$ (Table 3). Molasses $(p=0.007)$ and $\mathrm{FeSO}_{4}(p=0.025)$ had significant positive effects on the cell yield, respectively. Molasses is a frequently used industrial medium ingredient for the fermentation of various bacteria including Lactobacilli because of its cheap price and suitable for energy supply (Prado et al., 2016). It was reported that molasses could increase the growth efficiency in L. rhamnosus and $L$. delbrueckii (Senedese et al., 2015; Srivastava et al., 2015).

Concentration effects of medium ingredients on antibacterial activity: Broad antibacterial spectrums were found in runs of 3, 4, 11, 12, 14, 15 and 19 (Table 4). With these results, it could be supposed that the used medium ingredients and their concentrations could considerably influence the antibacterial activity in culture of L. plantarum SK1305. Sucrose showed a positive effect on antibacterial activity against all pathogens and it showed a particularly great effect against List. monocytogenes. All these effects were significant except for Sal. gallinarum ( $p=0.082)$. In L. plantarum, sucrose is known as a primary carbon source for improving cell growth, bacteriocin, and exopolysaccharides which are high molecular weight carbohydrate polymers synthesized by microorganisms including Lactobacillus (Cheng et al., 2019). However, there was a study reporting no effect of sucrose $(15$ or $30 \mathrm{~g} / \mathrm{L})$ on the production of bacteriocin (Sabo et al., 2019). In the present study, sucrose demonstrated as an important medium ingredient for the antibacterial activity of $L$. plantarum SK1305. Maltose is an important carbon source for LAB that can hydrolyze starch for the productions of lactic acid and bacteriocin (Reddy et al., 2008). It can be utilized for the bacteriocin production in L. plantarum that does not have amylolytic activity (Todorov and Dicks 2006). However, it was reported that bacteriocin production was not stimulated by $20 \mathrm{~g} / \mathrm{L}$ maltose (Todorov et al., 2013). In this study, maltose showed positive antibacterial effects against List. monocytogenes $(\mathrm{E}=3.3, \quad p=0.044)$ and Ent. faecalis $(\mathrm{E}=0.2, p=0.047)$. Molasses was shown as an important medium component in terms of cell yield and reported to be an important ingredient for the growth and bacteriocin production in L. delbrueckii (Srivastava et al., 2015). Sucrose is known as a major constituent in molasses (Prado et al., 2016). In the present study, high concentration of sucrose had positive effects on antibacterial activity against all pathogens in all runs. Therefore, molasses is expected to be a positive variable. However, the average effect of molasses was 0.7 , which was lower than the maltose $(\mathrm{E}=1.45)$. It had a negative antibacterial effect against Sal. typhimurium, whereas it had a significant positive effect against Sal. gallinarum $(p=0.045)$. Yeast extract had a negative effect on cell yield, while having positive effects against all tested pathogenic bacteria. In particular, yeast extract showed significant antibacterial effect against Sal. typhmurium $(p=0.026)$. Yoo et al. (2018) reported that yeast extract was positively influencing ingredient on cell yield. On the other hand, it was not effective on bacteriocin production in LAB according to Todorov and Dicks (2006).

Corn steep liquor (CSL) is rich in nutrient and cheap. The CSL has been reported as an essential medium component for the production of lactic acid from Lactobacillus sp., L. casei, and L. rhamnosus (Hwang et al., 2012; Li et al., 2016; Wee and Ryu 2009). The CSL showed a positive effect on antibacterial activity of $L$. plantarum SK1305 culture against all pathogenic bacteria except for Sal. typhimurium in this study. Whey showed positive antibacterial effects against List. monocytogenes, Burkholderia sp., Ent. Faecalis, and Sal. gallinarum, whereas its effects against Sal. typhimurium and Staph. aureus was negative. In addition, whey is known as a cheap and effective medium ingredient for the culture of 
LAB as like molasses and CSL. Whey is a by-product from milk processing and contains a lot of nutrients such as lactose, protein, fat, and minerals. Hence, whey can be utilized as both nitrogen and carbon source for the growth of LAB. Particularly, it is regarded as important for the productions of lactic acid and cell yield of LAB (Kim et al., 2006; Sweta and Samir 2016). Potassium phosphate is a phosphate source, essential for bacterial metabolism and it can improve the various fermentation efficiencies, such as cell yield and production of metabolites, via its buffering activity (Penna et al., 2005). However, potassium phosphate did not show positive effects on antibacterial activity against all tested pathogenic bacteria in this study $(p>0.05)$. Manganese and magnesium ions are important cofactors in the carbohydrate metabolism of LAB (Lew et al., 2012). Brillet-Viel et al. (2016) reported that these ions were also important for the production of bacteriocin. In this study, the effect of manganese sulfate was positive on cell yield, whereas it was negative on antibacterial activity. Contrary to the manganese sulfate, magnesium sulfate showed a negative effect on cell yield and a positive effect on the antibacterial activity. Tween 80 showed a positive effect against all pathogenic bacteria except Burkholderia sp. However, no significance was found $(p>0.05) . \mathrm{NaCl}$ showed antimicrobial effects against Sal. typhimurium and Sal. gallinarum but no significant effect $(p>0.05)$. Sodium acetate had positive antibacterial effects against all pathogenic bacteria and antibacterial effects against Sal. typhimurium, Burkholderia sp. and Sal. gallinarum were significant $(p<0.05)$. Ammonium citrate had positive antibacterial effect against all pathogenic bacteria but was not significant $(p>0.05)$. Sodium sulfate showed positive effects against Ent. faecalis and Staph. aureus but their significances were not found $(p>0.05)$. Ferrous sulfate showed positive effects on the antibacterial activity of L. plantarum SK1305 against Sal. typhimurium, List. monocytogenes, and Ent. faecalis, but those effects were not significant $(p>0.05)$.

\begin{abstract}
Standardized effects of media components on antibacterial spectrum: Summarized effect of ingredients against different pathogens are shown in Table 5. As the results, two ingredients, sucrose and sodium acetate,were detected as essential for the improvement and acquisition of antibacterial activity in the culture of $L$. plantarum SK1305. It was also found that sucrose and sodium acetate could get L. plantarum SK1305 specific antibacterial activity against Listeria monocytogenes and Burkholderia sp., respectively.
\end{abstract}

Table 1. Variables showing medium components used in Plackett-Burman design.

\begin{tabular}{|c|c|c|c|}
\hline Variables & Medium components & + Values (g/L) & - Values(g/L) \\
\hline $\mathrm{X} 1$ & Sucrose & 10 & 1 \\
\hline $\mathrm{X} 2$ & Maltose & 10 & 1 \\
\hline $\mathrm{X} 3$ & Molasses & 10 & 1 \\
\hline X4 & Yeast extract & 10 & 1 \\
\hline X5 & Corn steep liquor & 10 & 1 \\
\hline X6 & Whey & 10 & 1 \\
\hline $\mathrm{X} 7$ & $\mathrm{~K}_{2} \mathrm{HPO}_{4}$ & 2 & 0.2 \\
\hline X8 & $\mathrm{MnSO}_{4}$ & 0.05 & 0.025 \\
\hline X9 & $\mathrm{MgSO}_{4}$ & 0.05 & 0.025 \\
\hline $\mathrm{X} 10$ & Tween 80 & 1 & 0.1 \\
\hline $\mathrm{X} 11$ & $\mathrm{NaCl}$ & 5 & 0.5 \\
\hline $\mathrm{X} 12$ & $\mathrm{CH}_{3} \mathrm{COONa}$ & 5 & 0.5 \\
\hline $\mathrm{X} 13$ & $\mathrm{C}_{6} \mathrm{H}_{11} \mathrm{NO}_{7}$ & 2 & 0.2 \\
\hline $\mathrm{X} 14$ & $\mathrm{Na}_{2} \mathrm{SO}_{4}$ & 2 & 0.2 \\
\hline $\mathrm{X} 15$ & $\mathrm{FeSO}_{4}$ & 0.05 & 0.0025 \\
\hline
\end{tabular}

Table 2. Carbohydrate utilization profiles of L. plantarums SK1305.

\begin{tabular}{lccc}
\hline Substrate & Reactivity & Substrate & Reactivity \\
\hline Control & -1 & Galactose & + \\
Glycerol & - & Glucose & + \\
Erythritol & - & Fructose & + \\
D-Arabinose & - & Mannose & + \\
L-Arabinose & + & SorbosE & - \\
Ribose & + & Rhamnose & - \\
D-Xylose & - & Dulcitol & - \\
L-Xylose & - & Inositol & - \\
\hline
\end{tabular}




\begin{tabular}{lccc}
\hline Adonitol & - & Mannitol & + \\
Methyl-D-xyloside & - & Sorbitol & + \\
Methyl-D-mannoside & - & Melibiose & + \\
Methyl-D-glucoside & - & Sucrose & + \\
$N$-acetyl-glucosaine & + & Trehalose & + \\
Amygdalin & + & Inulin & - \\
Arbutin & + & Melezitose & + \\
Esculin & - & Raffinose & + \\
Salicin & + & Starch & - \\
Cellobiose & + & Glycogen & - \\
Maltose & + & Xylitol & - \\
Lactose & + & Gentiobiose & + \\
D-Turanose & + & D-Arabitol & - \\
D-Lyxose & - & L-Arabitol & - \\
D-Tagatose & - & Gluconate & + \\
D-Fucose & - & 2-keto-Gluconate & - \\
L-Fucose & - & $5-k e t o-G l u c o n a t e$ & - \\
\hline 1+ and - mean utilization and non-utilization of related carbohydrates, respectively & \\
&
\end{tabular}

Table 3. Viable cell yield and antibacterial activity results obtained from Plackett-Burman design configuration.

\begin{tabular}{|c|c|c|c|c|c|c|c|}
\hline \multirow{2}{*}{ Trials } & \multirow{2}{*}{$\begin{array}{c}\text { Cell yield } \\
\log _{10}(\mathrm{CFU} / \mathrm{ml})\end{array}$} & \multicolumn{6}{|c|}{ Clear zone diameter $(\mathrm{mm})$ against pathogenic bacteria ${ }^{1}$} \\
\hline & & $\mathbf{A}$ & B & $\mathbf{C}$ & D & $\mathbf{E}$ & $\mathbf{F}$ \\
\hline 1 & 9.43 & A & B & $\mathrm{C}$ & $\mathrm{D}$ & E & $\mathrm{F}$ \\
\hline 2 & 9.83 & $\mathrm{ND}^{2}$ & 16 & 15 & 15 & 12 & 16 \\
\hline 3 & 9.70 & ND & 16 & 10 & 13 & 12 & 13 \\
\hline 4 & 9.65 & 12 & 20 & 14 & 15 & 13 & 17 \\
\hline 5 & 9.36 & 13 & 20 & 10 & 15 & 12 & 16 \\
\hline 6 & 9.68 & ND & 17 & 12 & 15 & 12 & 15 \\
\hline 7 & 7.60 & 12 & 12 & 12 & 15 & 12 & ND \\
\hline 8 & 9.23 & ND & ND & 10 & ND & ND & 13 \\
\hline 9 & 9.51 & ND & 13 & 12 & 16 & 12 & 15 \\
\hline 10 & 9.28 & ND & 16 & ND & 14 & ND & 14 \\
\hline 11 & 9.45 & ND & 10 & ND & 13 & ND & 11 \\
\hline 12 & 8.11 & 10 & 14 & 14 & 13 & 13 & 14 \\
\hline 13 & 9.54 & 12 & 17 & 14 & 15 & 13 & 16 \\
\hline 14 & 9.92 & ND & 14 & 10 & 15 & 12 & 15 \\
\hline 15 & 9.92 & 13 & 20 & 13 & 16 & 12 & 16 \\
\hline 16 & 9.96 & 10 & 18 & 13 & 16 & 12 & 15 \\
\hline 17 & 9.91 & ND & 18 & 12 & 16 & 10 & 14 \\
\hline 18 & 9.64 & ND & 15 & 10 & 14 & 10 & 14 \\
\hline 19 & 8.04 & ND & 15 & 10 & 13 & 10 & 13 \\
\hline \multirow[t]{2}{*}{20} & 8.65 & 12 & 16 & 14 & 13 & 10 & 14 \\
\hline & & ND & ND & ND & ND & ND & ND \\
\hline
\end{tabular}

${ }^{1}$ A, Salmonella typhimurium; B, Listeria monocytogenes; C, Burkholderia sp., D, Enterococcus faecalis; E, Salmonella gallinarum, F, Staphylococcus aureus.

${ }^{2}$ ND: not detected. 
Table 4. Calculated effect and probability of media components for cell yield and antibacterial activity of $L$. plantarum SK1305.

\begin{tabular}{|c|c|c|c|c|c|c|c|c|c|c|c|c|c|c|}
\hline \multirow{3}{*}{$\begin{array}{l}\text { Media } \\
\text { components }\end{array}$} & \multirow{2}{*}{\multicolumn{2}{|c|}{ Cell yield }} & \multicolumn{12}{|c|}{ Antibacterial activity } \\
\hline & & & \multicolumn{2}{|c|}{$\begin{array}{l}\text { Salmonella } \\
\text { typhimurium }\end{array}$} & \multicolumn{2}{|c|}{$\begin{array}{l}\text { Listeria } \\
\text { monoytogenes }\end{array}$} & \multicolumn{2}{|c|}{ Burkhorderia sp } & \multicolumn{2}{|c|}{$\begin{array}{l}\text { Enterococcus } \\
\text { faecalis }\end{array}$} & \multicolumn{2}{|c|}{$\begin{array}{l}\text { Salmonella } \\
\text { gallinarum }\end{array}$} & \multicolumn{2}{|c|}{$\begin{array}{l}\text { Staphylococcus } \\
\text { aureus }\end{array}$} \\
\hline & Effect & $P$ value & Effect & $P$ value & Effect & $P$ value & Effect & $P$ value & Effect & $P$ value & Effect & $P$ value & Effect & $P$ value \\
\hline Sucrose & 0.90 & 0.087 & 1.80 & 0.011 & 4.30 & 0.001 & 1.80 & 0.049 & 2.00 & 0.029 & 1.80 & 0.082 & 2.70 & 0.012 \\
\hline Maltose & 1.00 & 0.110 & 0.20 & 0.442 & 3.30 & 0.044 & 0.60 & 0.172 & 2.00 & 0.047 & 0.90 & 0.079 & 1.70 & 0.056 \\
\hline Molasses & 1.76 & 0.007 & -0.60 & 0.288 & 1.70 & 0.119 & 0.80 & 0.256 & 1.40 & 0.100 & 1.70 & 0.045 & -0.80 & 0.333 \\
\hline Yeast extract & -0.44 & 0.231 & 2.60 & 0.026 & 1.90 & 0.148 & 1.20 & 0.179 & 0.20 & 0.440 & 0.30 & 0.397 & 0.50 & 0.358 \\
\hline Corn steep liquor & -0.40 & 0.280 & -1.00 & 0.172 & 0.10 & 0.476 & 0.60 & 0.327 & 0.20 & 0.432 & 0.30 & 0.332 & 1.70 & 0.086 \\
\hline Whey & 0.64 & 0.141 & -0.60 & 0.343 & 1.70 & 0.156 & 0.80 & 0.265 & 1.60 & 0.076 & 0.30 & 0.391 & -0.10 & 0.461 \\
\hline $\mathrm{K}_{2} \mathrm{HPO}_{4}$ & -0.14 & 0.332 & -0.20 & 0.442 & -0.90 & 0.329 & -0.20 & 0.440 & -0.60 & 0.528 & -1.10 & 0.149 & -0.70 & 0.293 \\
\hline $\mathrm{MnSO}_{4}$ & 0.25 & 0.385 & -1.00 & 0.204 & -0.30 & 0.433 & -0.50 & 0.391 & -0.40 & 0.370 & 0.10 & 0.464 & 0.90 & 0.202 \\
\hline $\mathrm{MgSO}_{4}$ & -0.20 & 0.391 & 1.00 & 0.197 & 2.70 & 0.094 & 0.80 & 0.270 & 1.00 & 0.199 & 1.30 & 0.098 & 2.10 & 0.068 \\
\hline Tween 80 & 0.32 & 0.354 & 0.40 & 0.373 & 1.30 & 0.280 & -0.40 & 0.382 & 1.40 & 0.117 & 0.50 & 0.315 & 0.50 & 0.357 \\
\hline $\mathrm{NaCl}$ & -0.39 & 0.109 & 1.20 & 0.159 & -0.90 & 0.320 & -0.20 & 0.445 & -0.60 & 0.315 & 0.30 & 0.397 & -0.70 & 0.293 \\
\hline $\mathrm{CH}_{3} \mathrm{COONa}$ & -0.38 & 0.331 & 1.60 & 0.024 & 0.70 & 0.331 & 3.20 & 0.002 & 1.00 & 0.235 & 2.10 & 0.028 & 1.30 & 0.115 \\
\hline $\mathrm{C}_{6} \mathrm{H}_{11} \mathrm{NO}_{7}$ & -0.09 & 0.459 & 0.00 & 0.500 & 0.10 & 0.473 & -0.60 & 0.314 & 0.80 & 0.270 & 0.30 & 0.351 & 0.10 & 0.469 \\
\hline $\mathrm{Na}_{2} \mathrm{SO}_{4}$ & 0.36 & 0.334 & -1.60 & 0.133 & -0.10 & 0.480 & -1.20 & 0.163 & 0.60 & 0.320 & -1.10 & 0.161 & 1.30 & 0.166 \\
\hline $\mathrm{FeSO}_{4}$ & 1.36 & 0.025 & 0.80 & 0.278 & 0.50 & 0.372 & -1.00 & 0.174 & 1.40 & 0.066 & -0.10 & 0.441 & -0.50 & 0.309 \\
\hline Standard error & 1.55 & & 7.81 & & 5.45 & & 5.26 & & 5.80 & & 4.25 & & 9.53 & \\
\hline
\end{tabular}

Table 5. Standardized effect ${ }^{1}$ of media components on antibacterial activity and their sum.

\begin{tabular}{|c|c|c|c|c|c|c|c|}
\hline \multirow{2}{*}{$\begin{array}{l}\text { Media } \\
\text { Components }\end{array}$} & \multicolumn{6}{|c|}{ Pathogenic bacteria } & \multirow[b]{2}{*}{$\begin{array}{l}\text { Sum } \\
\text { effect }\end{array}$} \\
\hline & $\begin{array}{c}\text { Salmonella } \\
\text { typhimurium }\end{array}$ & Listeria monocytogenes & Burkholderia sp. & $\begin{array}{c}\text { Enterococcus } \\
\text { faecalis }\end{array}$ & $\begin{array}{l}\text { Salmonella } \\
\text { gallinarum }\end{array}$ & Staphylococcus aureus & \\
\hline Sucrose & 118.31 & 2177.09 & 25.97 & 48.77 & 17.40 & 157.36 & 2544.89 \\
\hline Maltose & -0.21 & 34.14 & 1.15 & 30.09 & 5.49 & 17.14 & 87.80 \\
\hline Molasses & -2.74 & 3.55 & 1.47 & 7.07 & 29.25 & -4.09 & 34.51 \\
\hline Yeast extract & 76.87 & 3.77 & 4.10 & -1.61 & -0.57 & -0.43 & 82.13 \\
\hline Corn steep liquor & -6.62 & -1.38 & 0.60 & -1.64 & -0.69 & 11.16 & 1.44 \\
\hline Whey & -2.30 & 2.71 & 1.42 & 12.41 & -0.58 & -1.54 & 12.10 \\
\hline $\mathrm{K}_{2} \mathrm{HPO}_{4}$ & -1.00 & -4.05 & -1.18 & -3.12 & -11.89 & -4.33 & -25.58 \\
\hline $\mathrm{MnSO}_{4}$ & -5.58 & -2.14 & -2.02 & -3.82 & -0.97 & 1.07 & -13.45 \\
\hline $\mathrm{MgSO}_{4}$ & 3.07 & 11.68 & 1.39 & 1.18 & 8.93 & 19.57 & 45.83 \\
\hline Tween 80 & 0.22 & 0.55 & -1.83 & 6.04 & -0.02 & -0.43 & 4.52 \\
\hline $\mathrm{NaCl}$ & 4.90 & -4.16 & -1.17 & -5.24 & -0.57 & -4.33 & -10.58 \\
\hline $\mathrm{CH}_{3} \mathrm{COONa}$ & 46.96 & -0.76 & 1263.37 & 1.00 & 62.77 & 5.11 & 1378.45 \\
\hline $\mathrm{C}_{6} \mathrm{H}_{11} \mathrm{NO}_{7}$ & -0.53 & -1.39 & -2.80 & 0.00 & -0.65 & -1.12 & -6.49 \\
\hline $\mathrm{Na}_{2} \mathrm{SO}_{4}$ & -12.49 & -1.65 & -8.69 & -0.74 & -11.01 & 3.54 & -31.03 \\
\hline $\mathrm{FeSO}_{4}$ & 1.55 & -1.04 & -7.11 & 10.71 & -1.52 & -3.51 & -0.91 \\
\hline
\end{tabular}

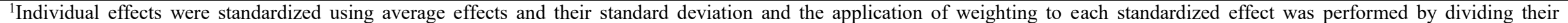
probability. 


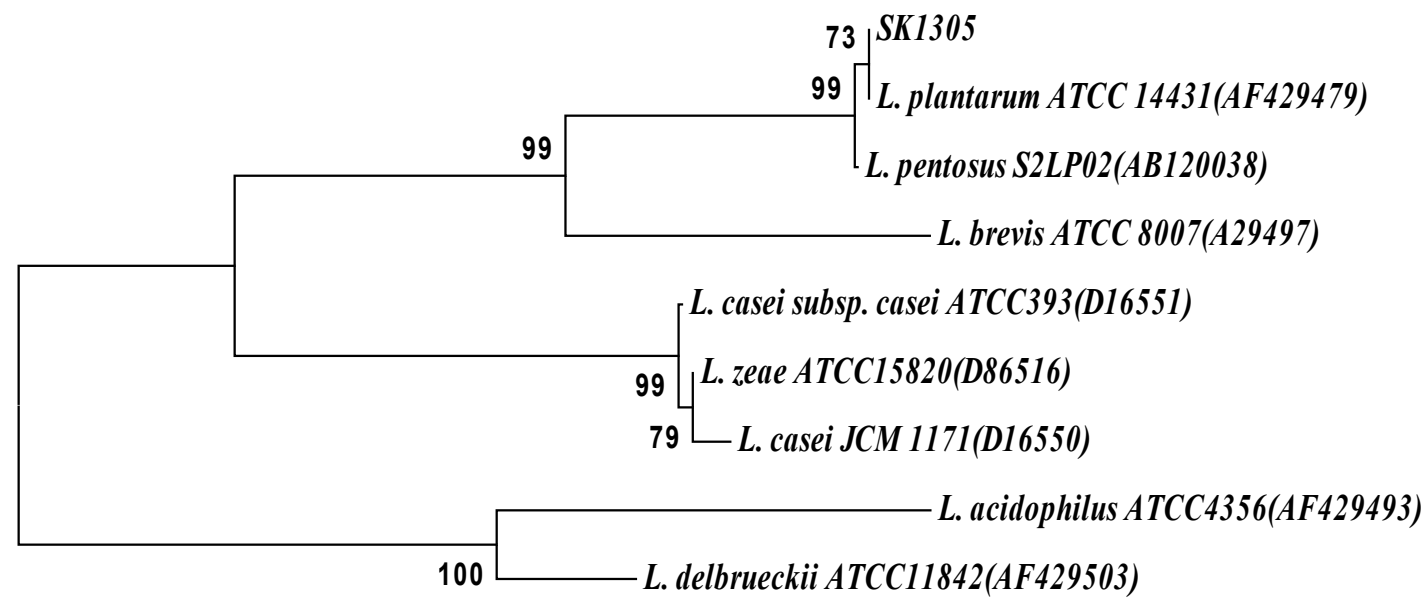

\section{$\longmapsto .01$}

Fig. 1. Phylogenetic tree of L. plantarum SK1305 with 8 type strains of Lactobacillus genus. Tree was built based on 16S rRNA gene sequences.

Conclusion: The present study isolated a bacteria, which was shown antibacterial activity, and it was identified as L. plantarum SK1305 based on 16S rRNA gene sequence analysis. Total of 15 medium ingredients were investigated for their effects on cell yield and antibacterial activity. Total of 20 experimental run based on PBD were employed. Various medium ingredients showed different effects on cell yield and antibacterial activities of L. plantarum SK1305. Through standardization of individual effects of ingredients, sucrose and sodium acetate were found as essential medium elements for the culture of isolated L. plantarum SK1305.

Acknowledgements: This work was supported by Korea Institute of Planning and Evaluation for Technology in Food, Agriculture, Forestry and Fisheries (IPET) through Agri-Bio Industry Technology Development Program, funded by Ministry of Agriculture, Food and Rural Affairs (MAFRA) (No. 312058-03 and 118051-03).

\section{REFERENCES}

Baradaran, A., H.L. Foo, and R.A. Rahim (2012). Isolation, identification and characterization of lactic acid bacteria from Polygonum minus. Rom. Biotechnol. Lett. 17:7245-7252.

Basualdo, C., V. Sgroy, M.S. Finola, and J.M. Marioli (2007). Comparison of the antibacterial activity of honey from different provenance against bacteria usually isolated from skin wounds. Vet. Microbiol. 124: 375-381.

Brillet-Viel, A., M.F. Pilet, P. Courcoux, H. Prevost, and F. Leroi (2016). Optimization of growth and bacteriocin activity of the food bioprotective
Carnobacterium divergens V41 in an animal origin protein free medium. Front. Mar. Sci. doi: 10.3389/fmars.2016.00128.

Castellano, P., M. P. Ibarreche, M. B. Massani, C. Fontana, and G.M. Vignolo (2017). Strategies for pathogen biocontrol using lactic acid bacteria and their metabolites: a focus on meat ecosystems and industrial environments. Microorganisms. $\quad$ 5: $38 . \quad$ doi: 10.3390/microorganisms5030038.

Chauhan, K., U. Trivedi, and K.C. Patel (2007). Statistical screening of medium components by Plackett-Burman design for lactic acid production by Lactobacillus sp. KCP01 using date juice. Bioresour. Technol. 98: 98-103.

Cheng, X., L. Huang, and K.T. Li (2019). Antioxidant activity changes of exopolysaccharides with different carbon sources from Lactobacillus plantarum LPC-1 and its metabolomic analysis. World J. Microbiol. Biotechnol. 35:68. doi: 10.1007/s11274- 019-2645-6.

Cho, S.B., W.K. Chang, Y.J. Kim, H.I. Moon, J.W. Joo, K.H. Seo, and S.K. Kim (2010). Effect of plant oils and minerals for the inhibition of lipase activity of Staphylococcus aureus isolated from fermented pork meat. Korean J. Food Sci. An. Resour. 30: 764-772.

Coman, G. and G. Bahrim (2011). Optimization of xylanase production by Streptomyces sp. P12137 using response surface methodology and central composite design. Ann. Microbiol. 61: 773-779.

Forte, C., L. Moscati, G. Acuti, C. Mugnai, M.P. Franciosini, S. Costarelli, G. Cobellis, and M. Trabalza-Marinucci (2016). Effects of dietary 
Lactobacillus acidophilus and Bacillus subtilis on laying performance, egg quality, blood biochemistry and immune response of organic laying hens. J. Anim. Physiol. Anim. Nutr. (Berl) 100:977-87.

Hwang, C.F., J.H. Chang, J.Y. Houng, C.C. Tsai, C.K. Lin, and H.Y. Tsen (2012). Optimization of medium composition for improving biomass production of Lactobacillus plantarum $\mathrm{Pi06}$ using the Taguchi array design and the BoxBehnken method. Biotechnol. Bioproc. E 17: 827-834.

Kim, H.O., Y.J. Wee, J.N. Kim, J.S. Yun, and H.W. Ryu (2006). Production of lactic acid from cheese whey by batch and repeated batch cultures of Lactobacillus sp. RKY2. Appl. Biochem. Biotechnol. 131: 694-704.

Lew, L.C., M.T. Liong, and C.Y. Gan (2012). Growth optimization of Lactobacillus rhamnosus FTDC 8313 and the production of putative dermal bioactives in the presence of manganese and magnesium ions. J. Appl. Microbiol. 114: 526535.

Li, X., W. Xu, J. Yang, H. Zhao, H. Xin, and Y. Zhang (2016). Effect of diferent levels of corn steep liquor addition on fermentation characteristics and aerobic stability of fresh rice straw silage. Animal Nutrition 2: 345-350.

Lindsay, B.G (1988). Composite likelihood methods. In: Prabhu, N.U., Ed., Statistical inference from stochastic processes, American Mathematical Society, Providence, 221-239.

Penna, T.C.V., A.F. Jozala, L.C. De Lencastre Novaes, A. Pessoa, and O. Cholewa (2005). Production of nisin by Lactococcus lactis in media with skimmed milk. Appl. Biochem. Biotechnol. 122:619-637.

Prado, M.R.M., S.G. Franco, and C.R. Soccol (2016). Development of a fermentation medium for production of probiotics and their use in feed for laying hens. Int. J. Curr. Microbiol. App. Sci. 5:357-369.

Reddy, G., M. Altaf, B.J. Naveena, M. Venkateshwar, and E.V. Kumar (2008). Amylolytic bacterial lactic acid fermentation - a review. Biotechnol. Adv. 26: 22-34

Ren, D., J. Zhu, S. Gong, H. Liu, and H. Yu (2018). Antimicrobial chatacteristics of lactic acid bacteria isolated from homemade fermented foods. Bio. Med. Res. Int. doi:10.1155/2018/5416725.

Sabo, S.S., A. Converti, S. Ichiwaki, and R.P.S. Oliveira (2019). Bacteriocin production by Lactobacillus plantarum ST16Pa in supplemented whey powder formulations. J. Dairy Sci. 102: 87-99.
Senedese, A.L.C., R.M. Filho, and M.R.W. Maciel (2015). L-Lactic acid production by Lactobacillus rhamnosus ATCC 10863. Scientic World J. doi: 10.1155/2015/501029.

Soni, P., M. Singh, A.L. Kamble, and U.C. Banerjee (2007). Response surface optimization of the critical medium components for carbonyl reductase production by Candida viswanathii MTCC 5158. Bioresour. Technol. 98: 829-833.

Srivastava, A.K., A.D. Tripathi, A. Jha, A. Poonia, and N. Sharma (2015). Production, optimization and characterization of lactic acid by Lactobacillus delbrueckii NCIM 2025 from utilizing agroindustrial byproduct (cane molasses). J. Food Sci. Technol. 52:3571-3578.

Sweta, A.P. and C.P. Samir (2016). Production of lactic acid from whey by Lactobacillus sp. isolated from local dairy products. Int. J. Curr. Microbiol. App. Sci. 5:734-741.

Tajabadi, N., M. Mardan, N. Saari, S. Mustafa, R. Bahreini, and M.Y.A. Manap (2013). Identification of Lactobacillus plantarum, Lactobacillus pentosus and Lactobacillus pfermentum from honey stomach of honeybee. Braz. J. Microbiol. 44:717-722.

Tamura, K., J. Dudley, M. Nei, and S. Kumar (2007). MEGA4: Molecular Evolutionary Genetics Analysis (MEGA) software version 4.0. Mol. Biol. Evol. 24: 1596-1599.

Tamura, K., M. Nei, and S. Kumar (2004). Prospects for inferring very large phylogenies by using the neighbor-joining method. Proc. Natl. Acad. Sci. U S A 101: 11030-11035.

Thompson, J.D., D.G. Higgins, and T.J. Gibson (1994). CLUSTAL W: improving the sensitivity of progressive multiple sequence alignment through sequence weighting, position-specific gap penalties and weight matrix choice. Nucleic Acids Res. 22: 4673-80.

Todorov, S.D. and L.M.T. Dicks (2006). Effect of medium components on bacteriocin production by Lactobacillus plantarum strains ST23LD and ST341LD, isolated from spoiled olive brine. Microbiol. Res. 161: 102-108.

Todorov, S.D., M. Vaz-Velho, B.D.G.M. Franco, and W.H. Holzapfel (2013). Partial characterization of bacteriocins produced by three strains of Lactobacillus sakei, isolated from salpicao, a fermented meat product from North-West of Portugal. Food Control 30: 111-121.

Vieco-Saiz, N., Y. Belguesmia, R. Raspoet, E. Auclair, F. Gancel, I. Kempf, and D. Drider (2019). Benefits and inputs from lactic acid bacteria and their bacteriocins as alternatives to antibiotic growth promoters during food-animal production. Front. Microbiol. 10: 57. doi: 
10.3389/fmicb.2019.00057.

Wang, L., C. Liu, M. Chen, T. Ya, W. Huang, P. Gao, and H. Zhang (2015). A novel Lactobacillus plantarum strain P-8 activates beneficial immune response of broiler chickens. Int. Immunopharmacol. 29: 901-907.

Wee, Y.J. and H.W. Ryu (2009). Lactic acid production by Lactobacillus sp. RKY2 in a cell-recycle continuous fermentation using lignocellulosic hydrolyzates as inexpensive raw materials. Bioresour. Technol. 100:4262-70.

Weiburg, W.G., S.M. Barns, D.A. Pelletier, and D.J. Lane (1991). 16S ribosomal DNA amplification for phylogenetic study. J. Bacteriol. 173: 697703.

Yang, E., L. Fan, J. Yan, Y. Jiang, C. Doucette, S.
Fillmore, and B. Walker (2018). Influence of culture media, $\mathrm{pH}$ and temperature on growth and bacteriocin production of bacteriocinogenic lactic acid bacteria. AMB Express doi:10.1186/s13568-018-0536-0.

Yoo, H., I. Rheem, S. Rheem, and S. Oh (2018). Optimizing medium components for the maximum growth of Lactobacillus plantarum JNU 2116 using response surface methodology. Korean J. Food Sci. An. 38:240-250.

Zhang, Y.J., Q. Li, Y.X. Zhang, D. Wang, and J.M. Xing (2012). Optimization of succinic acid fermentation with Actinobacillus succinogenes by response surface methodology (RSM). J. Zhejiang Univ. Sci. B. 13:103-110. 